DOI:10.17951/k.2016.23.1.33

\begin{tabular}{lcl}
\hline \multicolumn{1}{c}{ A N N A L E S } \\
UNIVERSITATIS MARIAE CURIE-SKŁODOWSKA \\
LUBLIN - POLONIA \\
VOL. XXIII, 1 & SECTIO K & 2016 \\
\hline
\end{tabular}

Faculty of Political Science, Maria Curie-Skłodowska University in Lublin, Poland

\title{
China's "One Belt, One Road” Initiative - the Perspective of the European Union
}

China is like an adolescent who took too many steroids. It has suddenly become big, but it finds it hard to coordinate and control its body. To the West, it can look like a monster

[Jacobs 2009]

\begin{abstract}
The idea of "One Belt, One Road" will promote China as a soft power and attractive player in the global market. It is related to China's perception of global changes brought about by financial crisis, and growing world-wide interdependence. Beijing's initiative aims at the potential for increased economic exchanges between China and Europe. In fact, "One Belt, One Road" (OBOR) can be called a comprehensive domestic and foreign policy concept. Historically, the concept of the "Silk Road" was not only about trade, but also had significant cultural meaning. The OBOR initiative could serve as a cultural bridge between Europe and China, which should not only be understood as "two markets" and "two forces," but also as "two civilizations". This concept might be especially profitable for Central and Eastern European countries which focus on strengthening relations with the PRC after years of mutual insignificance and strive for balancing huge trade deficit and attracting Chinese investments.
\end{abstract}

Key words: "One Belt, One Road", China, the European Union 


\section{INTRODUCTION}

In mid 2013, Xi Jinping initiated the "Silk Road (SR) Economic Belt" idea, and a month later he announced the "21-st Century Maritime Silk Road" concept [Szczudlik-Tatar 2015: 1-2]. The idea was to boost economic and political relations with neighboring countries. The "Economic Belt" would serve this purpose for China's western and inland central Asian states, while the "Maritime Silk Road" would do so for Southeast Asian states. Beijing's "Silk Road Economic Belt" initiative aims at the potential for increased economic exchanges between China and Europe. However, the initiative could also provide an opportunity for cooperation on regional security between the two sides [Brauner 2014]. In mid 2014, another slogan was announced - "One Belt, One Road" - which is used interchangeably with the term "Silk Road" [Kaczmarski 2015: 1-9]. The term "Silk Road" has been in use since the nineteenth century and refers to the traditional east-west trading network across Eurasia and the Indian Ocean region. By using this term, the Chinese government emphasizes the commercial and open nature of the modern version of this network. At the same time, the term evokes memories of China's past as a strong and prosperous country - a status that China's current leadership is trying to restore under an approach that it calls the "Chinese dream".

\section{THE RISE OF CHINA}

China's rapid rise has caught the world by surprise, partly because of its scale and speed. Since the 2008 world economic crisis, the precipitous decline of influence of the United States and the European Union on world affairs has been underscored by the undaunted ascendancy of China as the second largest economy, and, unsurprisingly, by its global influence.

The rise of China will undoubtedly be one of the great "dramas of the twenty-first century" [Ikenberry 2008]. China's extraordinary economic growth and active diplomacy are already transforming East Asia, and future decades will see even greater increases in Chinese power and influence. But how exactly this drama will play out is an open question. Will China overthrow the existing order or become a part of it? And what, if anything, can the West do to maintain its position as China rises? [Ikenberry 2008].

China maintains the principle of non-interference in the domestic affairs of other countries, which limits its ability to protect its interests and citizens in overseas crisis zones, but it helps it to make business with countries with different values and political systems.

The rise of China is a complicated phenomenon with a multifarious nature, including material dimensions, such as military power, economic development, and technological innovation, as well as ideational dimensions, such as perception, understanding, or prejudice. 
Ian Bremmer who runs Eurasia Group, a leading global political risk think tank, draws a conclusion that China's global influence is rather limited: "although China's economic influence is growing, its power to influence other nations is slight. It has achieved little of what policymakers call "capture," a condition in which economic or security dependence of one country on another allows the more powerful to drive the other's policy making" [Bremmer 2013]. And in terms of 'soft power' influence, Bremmer continues, "China's political and economic systems have little appeal in other countries. Its state capitalist economic model attracts political leaders looking to build wealth and micromanage markets, but it offers little for ordinary citizens" [Bremmer 2013].

Chinese government has stepped up efforts to build 'cultural soft power' across the world, and promoted 'public diplomacy' as an important part of its foreign policy implementations. Moreover, in the age of the Internet and social media, public opinion has inevitably affected policies and deals in trade relations, geopolitical negotiations, and other international affairs ${ }^{1}$.

The Pew and BBC surveys poll the public opinion of various countries on China, aiming at a comprehensive assessment of the overall impressions of China's rise visà-vis the United States'. The 2013 Pew Global Attitude Survey states that: "publics around the world believe the global balance of power is shifting. China's economic power is on the rise, and many think it will eventually supplant the United States as the world's dominant superpower. However, China's increasing power has not led to more positive ratings for the People's Republic. Overall, the US enjoys a stronger global image than China. Across the nations surveyed, a median of $63 \%$ express a favorable opinion of the US, compared with 50\% for China" [America's Global Image 2013].

A "Rising China" has been a major, but under-analyzed development in the international system. Speculating about what a rival Chinese superpower means for the international order has become common practice [Rising China 2009].

The European Union is no exception in this: China-related issues (such as trade, human rights, development policy and the export of military equipment) have increasingly moved up the EU's agenda, and in the last decade the EU has pushed hard for an intensification and improvement in Sino-European relations [Rising China 2009].

Economic factors have driven this increased awareness, although lately the EU has attempted to give the dialogue a greater political component. The current recession might have its repercussions in this process, as both the EU and China see economic contraction in the short term and potentially into the medium term as well, but ultimately these economic giants will remain "poaching on each other's territory" [Rising China 2009].

\footnotetext{
1 See more: Rising Soft Powers. China, Los Angeles 2015.

2 See more: I. d'Hooghe, The Limits of China's Soft Power in Europe. Beijing 's Public Diplomacy
} Puzzle, Haga 2010. 


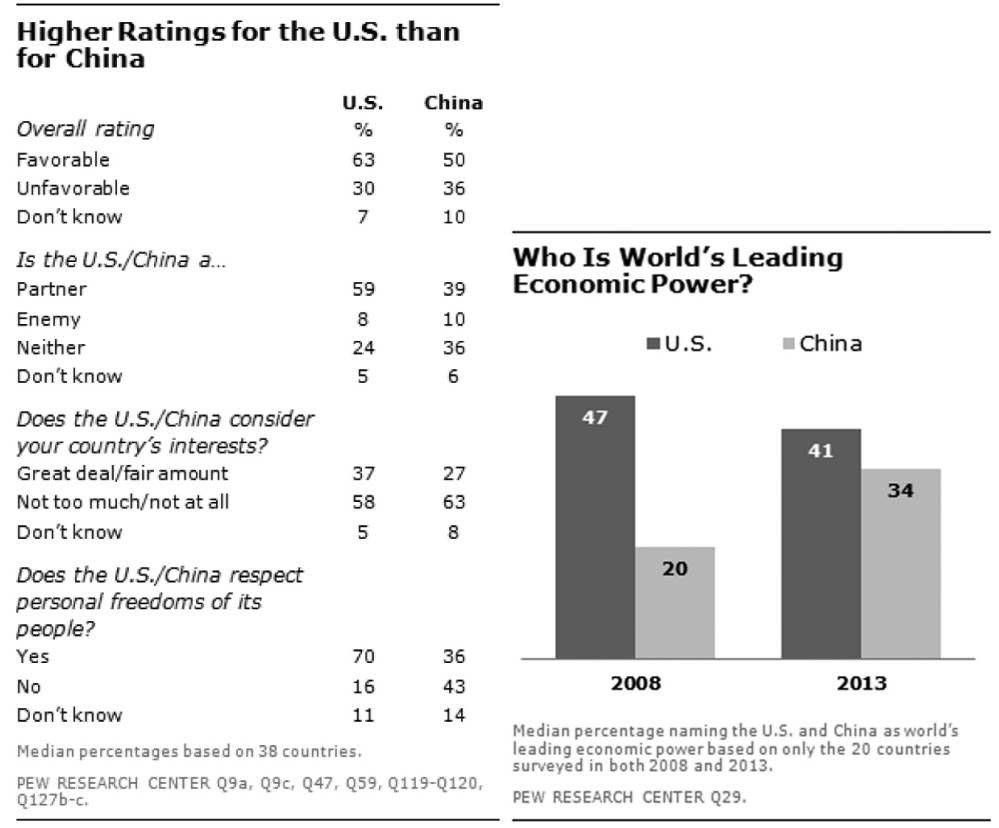

Figure 1. Pew Research Center survey

Source: http://www.pewglobal.org/2013/07/18/americas-global-image-remains-more-positive-than-chinas/

In contrast to many American policy stances on China, the EU has generally judged Chinese ascendancy in a positive light, and has approached it in the spirit of cautious optimism, stressing partnership based on common interests and common values. However, as China increasingly shows "appetite to combine economic weight with political assertiveness", the EU is slowly adopting a more cautious and realistic approach [Rising China 2009].

\section{THE IDEA OF “ONE BELT, ONE ROAD”}

It is not really clear yet what "One Belt, One Road" will mean in concrete terms. It is a broad vision to connect China with Europe. Its goal is to bring stability to the countries connected by the Silk Road through development [Wacker 2014]. Although the plan is still nebulous, there are some details that indicate China's main goals. These are, "to be a rule-maker and contributor to the global economy, to internationalize Chinese contractors and currency, to upgrade technology and production capacity, and so on. China wants to be more responsible for the development in the global scale (负责任大国). As a result, China intends to restructure its economy as a "new opening up" [Szczudlik-Tatar 2015: 1-2]. The idea of "One Belt, One Road" is a skilful means for China to demonstrate its active and peaceful agenda, which is 
not directed against any other country, and to highlight the Chinese charm offensive based on a "win-win" philosophy [Szczudlik-Tatar 2015: 1-2]. This concept will promote China as a soft power and attractive partner for everybody. The usage of the words "proposal", "vision" and "framework" instead of a "strategy" is also the specificity of the OBOR initiative. In that sense, China highlights that the concept has no political goals, that it is not a political tool to exert pressure on others.

In fact, "One Belt, One Road" can be called a comprehensive domestic and foreign policy concept. It is based on Chinese interests, political and economic, including domestic development. The main interests are related to China's perception of global changes brought about by financial crisis, and growing world-wide interdependence. China, which has coped quite well with the crisis, and still has a stable economy, would like to make its own contribution to the global economy and politics as a means of indicating its ascendancy [Szczudlik-Tatar 2015: 1-2].

In this context, we have to mention the list of desired areas of economic cooperation within OBOR:

a) exports for securing outlets for China's products, and imports for acquiring raw materials and new technologies,

b) establishing free trade areas, signing agreements on avoidance of double taxation,

c) expanding the scope of economic cooperation in areas such as agriculture, maritime industries, energy, green technologies and more,

d) financial cooperation - creation of new institutions such as the Asia Infrastructure and Investment Bank, the Silk Road Fund, the BRICS New Development Bank, and so on, in order to stimulate investments and eliminate infrastructure bottlenecks that limit regional development.

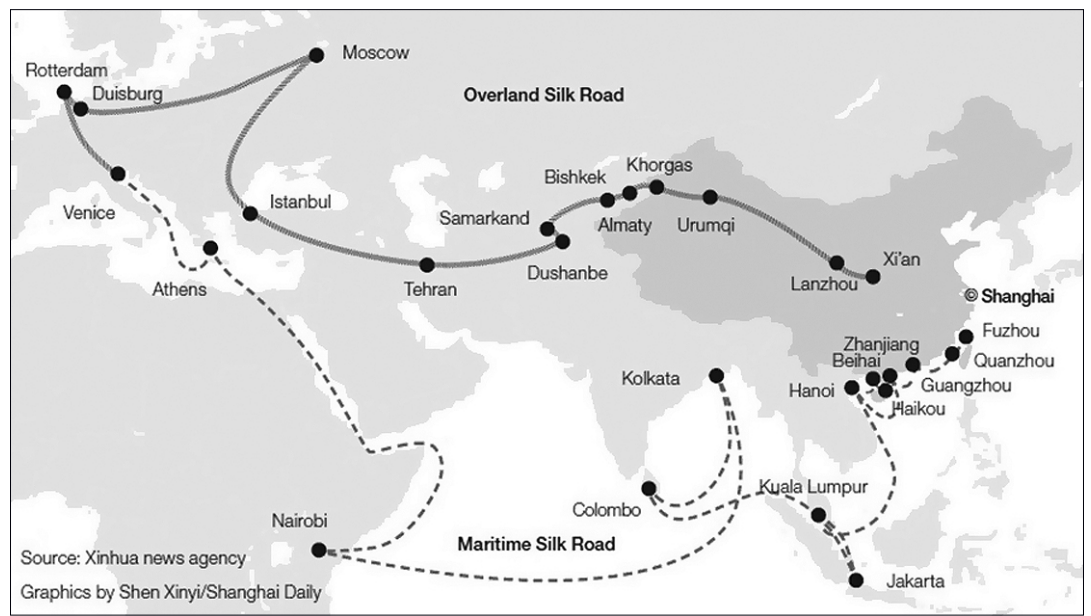

Map 1. The Economic Belt and the 21st-century Maritime Silk Road 
Although there is no a detailed map of "One Belt, One Road", the concept presents regions that are involved, both within China and outside of it. It lists almost all provinces, main cities, and inland and coastal Chinese areas, indicating that this is a comprehensive project that should contribute to the development of the PRC as a whole. The SR outside China spans three continents, Asia, Europe and Africa. The "Economic Belt" contains Central Asia, South-East Asia, Russia, Europe (including the Baltic Sea), the Persian Gulf and the Mediterranean Sea, and the " $21^{\text {st }}$ Century Maritime Silk Road" embraces harbors along China's coasts, the South China Sea, the Pacific Ocean, the Indian Ocean and Europe ${ }^{3}$. The "Maritime Silk Road", as envisioned by China, will greatly improve connections between the western Pacific, the Indian Ocean and the Mediterranean Sea, between South Asia and East Africa, and between East Asia and Europe. China's initiative for the so-called " $21^{\text {st }}$-Century Maritime Silk Road" is aimed at port development in South-East Asia, around the Indian Ocean and in the eastern Mediterranean region [van der Putten, Meijnders 2015: 9]. China's involvement in ports and other maritime infrastructure should be seen in the context of its broader infrastructure activities under the "One Belt, One Road" programme. Sea lanes and railways complement each other, and jointly open up new trade links between regions [Cameron 2015].

"Silk Road Economic Belt" connects China and Europe via Kazakhstan, Russia and Belarus, which are increasingly used for transporting goods, mainly from China to Europe. A railway route between China and Europe that bypasses Russia is also expected to be available in the future. It will connect Central Asia and Turkey via Azerbaijan and Georgia. Chinese government is also considering a plan for a direct railway line between China and the United Kingdom via Kazakhstan, Uzbekistan, Turkmenistan, Iran, Turkey, Bulgaria, Romania, Hungary, Austria, Germany, Belgium and France. Since late 2013, the Chinese government has announced plans to construct high-speed railways from Piraeus via Skopje and Belgrade to Budapest, and from the Black Sea port of Constanta via Bucharest and Budapest to Vienna [van der Putten, Meijnders 2015: 12]. If these new lines indeed materialize, then this regional network could potentially be extended east to link to China's national rail system, and west to cover more parts of Europe [van der Putten, Meijnders 2015: 9].

The "One Belt, One Road" conception has many dimensions: economical and political are crucial, but its success is not possible without good promotion and information in participating countries and in China. To realize this aim it is necessary to organize the cultural events, expert meetings or scientific conferences.

3 See more: "One Belt, One Road": China's great leap outward, http://www.ecfr.eu/page//China analysis_belt_road.pdf; Reviving the Silk Road: What is Behind It?, "Madariaga Report", 24 April 2015, http://www.madariaga.org/ 
According to Oliver Bräuner, a researcher for the China and Global Security Programme at SIPRI, we can mention three main challenges for EU-China cooperation: diverging interests, competing structures and external influences which are obstacles for China-EU cooperation on security and in other areas [Bräuner 2014]. Both sides compete for natural resources (especially oil and gas) and increasingly also for markets in this region [Misiągiewicz, Misiągiewicz 2014: 64-80]. In addition, it needs to be ensured that the countries along the 'Silk Road Economic Belt' can also benefit from the initiative - and not just through economic growth, but also through employment opportunities for locals [Bräuner 2014].

Moreover, the 'Silk Road Economic Belt' initiative is competing with a tangle of organizations (EU, NATO, CSTO - the Collective Security Treaty Organization, Eurasian Union), forums (ASEM - the Asia-Europe Meeting, CICA - the Conference on Interaction and Confidence-Building Measures in Asia) and concepts (ENP - the European Neighborhood Policy, or US New Silk Road Strategy) [Bräuner 2014].

Another problem are the interests of external actors and the overlapping geopolitical spheres of interest of major powers. Russia seems to be increasingly aggressive in defending its spheres of interest originating from the former Soviet empire. While the US is further reducing its presence in Afghanistan and in Central Asia, the recent advances of IS have drawn it deeper into the conflict in Syria and in Iraq. Other actors with an interest in the region include Japan, South Korea, India, Iran and Pakistan. In addition, some Central Asian countries are also trying to establish themselves as more independent regional powers, especially Kazakhstan with its 'multi-vector' foreign policy [Bräuner 2014].

At least two main concepts could potentially compete with OBOR:

- US initiative of a New Silk Road launched in 2012 - goal: reconnecting Afghanistan to the rest of the region;

- More importantly: Russia's project to create an integrated Eurasian space - Eurasian Union - not only economically, but also in terms of security (Collective Treaty Organisation or CSTO) - existing in parallel to the Shanghai Cooperation Organization (SCO) [Wacker 2014].

\section{EU-CHINA RELATIONS}

Despite the seriousness with which Asian countries are taking the initiative and its tremendous potential impact on the Eurasian continent, the European Union has to date been slow and reluctant in responding to the "One Belt, One Road" idea [Yan 2015]. There is little academic research in European academia on the OBOR initiative, nor any real discussion at the official level. The subject has been also missing from the official EU-China dialogue [Yan 2015]. 
According to the EU-China 2020 Strategic Agenda for Cooperation, there are stakes for the EU in at least three areas: trade and investment, peace and security, and people-to-people exchange [EU-China 2020 Strategic Agenda for Cooperation]. In this strategy, it is important to "strengthen coordination and cooperation, working for just, reasonable, and effective rules in key fields, such as international trade and investment, finance, environment and climate change, the Internet and a new generation of wireless communication technology" [EU-China 2020 Strategic Agenda for Cooperation].

Trade and commerce have been at the core of EU-China relationship. The EU has been China's largest trading partner since 2004, and China is the EU's second largest trading partner. Two-way trade reached $\$ 615.1$ billion in 2014 [Yan 2015]. This trade interdependence should be a major incentive for the EU to pay close attention to and engage in the OBOR project. As trade is highly reliant on transport infrastructure, the OBOR concept is to have implications for EU-China trade [Yan 2015]. It has potential to enlarge and accelerate the movements of goods between China and Europe. European economic growth would be stimulated through the connections extending the EU single market into Eurasia. Europe could cooperate with China by taking advantage of its advanced technology, capital, and management experience [Yan 2015].

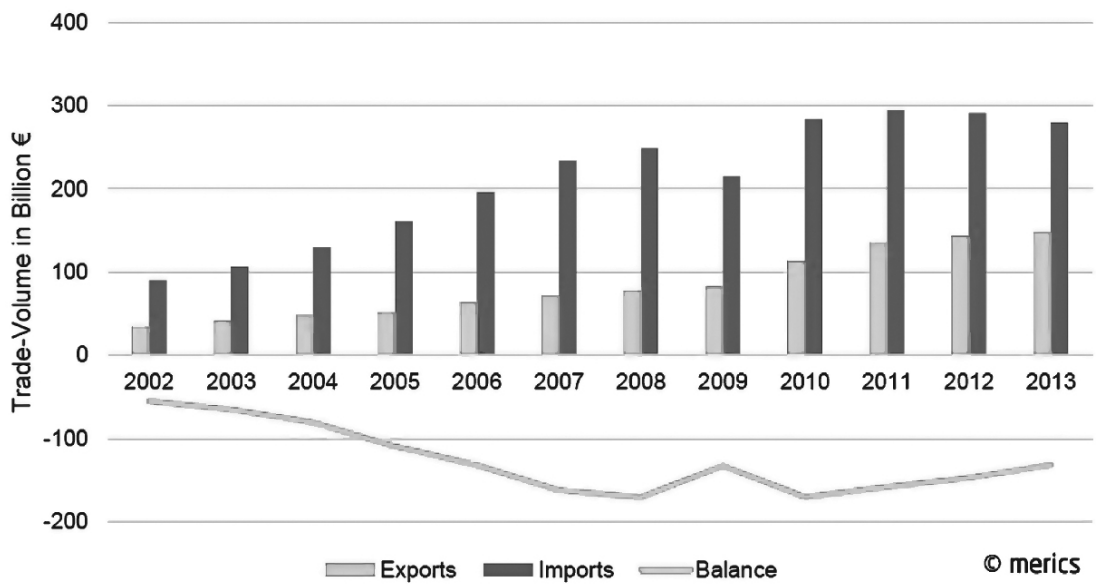

Figure 2. EU-China Trade-Volume and Trade-Balance

Source: http://www.merics.org/programme/internationale-beziehungen/wine-solar-panels-and-rare-earths.html

Development and security are closely linked, and this connection is included in the EU-China 2020 Strategic Agenda for Cooperation. According to this document, "As important actors in a multipolar world, the EU and China commit to enhancing dialogue and coordination at bilateral, regional and global levels, to meet regional and global challenges together, and work to make the international order and system more just and equitable" [EU-China 2020 Strategic Agenda for Cooperation].

According to Oliver Bräuner, "the current crises in the Middle East and Ukraine and the deterioration of the EU-Russian relationship question the feasibility of Chi- 
na's 'Silk Road Economic Belt' initiative” [Bräuner 2014]. In addition, he said: "both China and the EU have a common interest in stemming the flow of conflict-sensitive, destabilizing or illicit commodities, such as conventional arms and narcotics, in Afghanistan and Central Asia. This provides the opportunity for a greater exchange of experiences between China (...) and the EU on capacity building for regional states, especially with regard to strengthening border controls (...) Both sides should coordinate and discuss potential similar future scenarios in the Middle East and Central Asia. The area of non-combatant evacuation operations could also provide a relatively uncontroversial area of cooperation between European militaries and the Chinese People's Liberation Army" [Bräuner 2014]. In an insecure region it is impossible to make good business.

Historically, the concept of the Silk Road was not only about trade, but also had significant cultural meaning. The OBOR initiative could serve as a cultural bridge between Europe and China, which should not only be understood as "two markets" and "two forces," but also as "two civilizations" [Yan 2015]. As OBOR cuts across the world's major civilizations, it is expected to bring a new opportunity and possibility for global integration.

\section{CONCLUSIONS}

Thus, the EU and its member states are not outsiders but stakeholders in the "One Belt, One Road" initiative. As China invites more European countries to participate in the project, the EU will be under pressure to coordinate a common European response.

OBOR is an entry point for the EU into Asia-Pacific affairs. Europe will also find the opportunity to balance its transatlantic relationship. It is faced with an opportunity to return to the "centre of the world" through the revival of Eurasia [Yan 2015]. Since the United States put forward its "return to Asia" strategy, the EU has been concerned it will be marginalized. EU efforts to accelerate the promotion of free trade agreements with Asian countries is less-than-satisfactory progress. OBOR would make it much easier for Europe to participate in global affairs [Yiwei 2015].

\section{BIBLIOGRAPHY}

America's Global Image Remains More Positive than China's, 2013. "Pew Research Center", 18 July, http://www.pewglobal.org/2013/07/18/americas-global-image-remains-more-positive-than-chinas/ (access 12.10.2015).

Bräuner, O. 2014. Deepening China-EU security cooperation along the 'Silk Road Economic Belt', "Friends of Europe", 24 October, http://www.friendsofeurope.org/global-europe/deepening-china-eu-security-cooperation-along-silk-road-economic-belt/ (access 12.10.2015).

Bremmer, I. 2013. China's Limited Influence, "The New York Times”, 27 November. 
Cameron, F. 2015. The Maritime Silk Road - an EU perspective, "World Commerce Review", June, http:// www.worldcommercereview.com/publications/article pdf/961 (access 13.10.2015).

D'Hooghe, I. 2010. The Limits of China's Soft Power in Europe. Beijing's Public Diplomacy Puzzle, Netherlands Institute of International Relations, Hague.

EU-China 2020 Strategic Agenda for Cooperation, http://eeas.europa.eu/china/docs/eu-china_2020_strategic_agenda_en.pdf (access 13.10.2015).

Ikenberry, G. J. 2008. The Rise of China and the Future of the West. Can the Liberal System Survive?, "Foreign Affairs" January/February.

Jacobs, A. 2009. China hunts for art treasures in U.S. museums, "New York Times", 17 December.

Kaczmarski, M. 2015. The New Silk Road: a versatile instrument in China's policy, "OSW Commentary", http://www.osw.waw.pl/en/publikacje/osw-commentary/2015-02-10/new-silk-road-a-versatile-instrument-chinas-policy (access 12.10.2015).

Misiągiewicz, J., Misiągiewicz, M. 2014. The Caspian region and its significance for the energy security policy of China, "The Journal of China and the World", chapter 9.

"One Belt, One Road": China's great leap outward, 2015. "China Analysis" European Council on Foreign Relations, http://www.ecfr.eu/page//China_analysis_belt_road.pdf (access 13.10.2015).

Reviving the Silk Road: What is Behind It?, 2015. "Madariaga Report", 24 April, http://www.madariaga. org/ (access 13.10.2015).

Rising China: EU Perspectives and Responses, 2009. European Union Center of North Carolina, "EU Briefings", April.

Rising Soft Powers. China, 2015. USC, Center on Public Diplomacy, Los Angeles.

Szczudlik-Tatar, J. 2015. "One Belt, One Road": Mapping China's New Diplomatic Strategy, "Bulletin PISM", no. 67 (799).

Van der Putten, F. P., Meijnders, M. 2015. China, Europe and the Maritime Silk Road, Hague.

Wacker, G. 2014. Shared Destiny: New Silk Road between China and Europe, "Friends of Europe", 24 October, http://www.friendsofeurope.org/global-europe/shared-destiny-new-silk-road-china-europe/ (access 13.10.2015).

Yan, S. 2015. Why the 'One Belt One Road' Initiative Matters for the EU. China's grand initiative represents all sorts of opportunities for Europe, http://thediplomat.com/2015/04/why-the-one-belt-one-roadinitiative-matters-for-the-eu/ 9 April, (access 13.10.2015).

Yiwei, W. 2015. One Belt One Road: Opportunities for Europe-China cooperation, "Europe's World", 13 May, http://europesworld.org/2015/05/13/one-belt-one-road-opportunities-europe-china-cooperation/\#.Vl2X179jROY (access 13.10.2015).

\section{BIOGRAPHIES}

Justyna Misiągiewicz, $\mathrm{PhD}$, Assistant Professor, Department of International Relations, Faculty of Political Science, Maria Curie-Skłodowska University, Lublin. E-mail: justyna.misiagiewicz@poczta.umcs.lublin.pl

Marcin Misiągiewicz, PhD candidate, Department of International Relations, Faculty of Political Science, Maria Curie-Skłodowska University, Lublin. E-mail: marcinmisiagiewicz@gmail.com 